\title{
Characterization of $5-\mathrm{HT}_{3}$ Receptor Mutations Identified in Schizophrenic Patients
}

\author{
Andrew J. Thompson ${ }^{1}$, Nora L. Sullivan², and Sarah C. R. Lummis ${ }^{*}, 1$ \\ ${ }^{1}$ Department of Biochemistry, University of Cambridge, Cambridge, UK \\ ${ }^{2}$ Department of Microbiology and Molecular Genetics, Harvard Medical School, Boston, MA
}

\section{Abstract}

The 5- $\mathrm{HT}_{3}$ receptor is a member of the Cys-loop family of ligand-gated ion channels, proteins that have been implicated in the pathology of several neurological disorders. In this study, we examine two mutations $\left(\mathrm{R}^{344} \mathrm{H}\right.$ and $\left.\mathrm{P}^{391} \mathrm{R}\right)$ that have been previously identified in individuals diagnosed with schizophrenia. These mutations are located in the M3-M4 loop of the 5- $\mathrm{HT}_{3}$ receptor and their occurrence presents the possibility that they contribute toward the etiology of this disorder. Radioligand binding with the 5-HT receptor antagonist, $\left[{ }^{3} \mathrm{H}\right]$ granisetron, revealed no significant difference in receptor affinity or density between mutant and wild-type receptors when expressed in HEK293 cells. However, comparison of $\mathrm{EC}_{50}$ values using whole-cell patch clamp for wildtype (1.68 $\mu M \pm 0.01, n=38), \mathrm{R}^{344} \mathrm{H}(1.70 \mu M \pm 0.02, n=18)$, and $\mathrm{P}^{391} \mathrm{R}(2.73 \mu M \pm 0.01, n=$ 8) receptors revealed a significant increase in the $\mathrm{EC}_{50}$ of the $\mathrm{P}^{391} \mathrm{R}$ mutant. Analysis of Hill coefficients, and activation and desensitization rate constants showed no significant difference between wild-type and mutant receptors. These data suggest that the $\mathrm{P}^{391} \mathrm{R}$, but not the $\mathrm{R}^{344} \mathrm{H}$, mutation may play a role in the pathology of schizophrenia.

\section{Keywords}

Serotonin receptor; ligand-gated ion channel; binding site; $5-\mathrm{HT}_{3}$ receptor; schizophrenia; intracellular loop; whole-cell patch clamp; intracellular mutation; Cys-loop receptor; M3-M4

\section{Introduction}

The theory of 5-HT involvement in schizophrenia was presented in 1954, and proposed that there was a serotonergic deficiency in schizophrenic individuals (Gaddum and Hameed, 1954; Wooley and Shaw, 1954). Serotonin receptors have been implicated in many of the symptoms of schizophrenia, and are prime candidates because of their functional diversity and their ability to modulate the release of other neurotransmitters such as dopamine (Alex et al., 2005; Meltzer, 1989). To date, the focus of 5-HT and its impact on schizophrenia has largely been on the $5-\mathrm{HT}_{2}$ receptors, for which there is a large amount of evidence. However, drugs such as clozapine and ondansetron, which are known to have positive effects on schizophrenic symptoms, are potent 5- $\mathrm{HT}_{3}$ receptor antagonists (Levkovitz et al., 2005; Meltzer et al., 2003; Meltzer and Fatemi, 1996), and so it is possible that these receptors play a role in the disorder.

\footnotetext{
Copyright (C) 2006 Humana Press Inc.

*Author to whom all correspondence and reprint requests should be addressed. E-mail: s1120@ mole.bio.cam.ac.uk.
} 
The 5- $\mathrm{HT}_{3}$ receptor is unique among the serotonin receptor family, as it contains an integral, agonist-gated ion channel, unlike all other known serotonin receptors, whose actions are mediated via $\mathrm{G}$ proteins (Maricq et al., 1991). It is a member of the Cys-loop of ligand-gated ion channels, which also includes nicotinic acetylcholine (nACh), glycine, and $\mathrm{GABA}_{\mathrm{A}}$ receptors. These proteins share a similar structure that consists of five subunits surrounding a central ion-conducting pore. Each subunit has a large extracellular domain, which contains the ligand-binding site, four transmembrane a-helices (M1-M4), and an intracellular loop that lies between M3 and M4 (Fig. 1). Native receptors are usually heteromeric and, to date, two $5-\mathrm{HT}_{3}$ receptor subunits have been characterized, namely $5-\mathrm{HT}_{3 \mathrm{~A}}$ and $5-\mathrm{HT}_{3 \mathrm{~B}}$ (Davies et al., 1999; Dubin et al., 2000). However, the 5- $\mathrm{HT}_{3}$ receptor is unusual in that it can form functional homomeric assemblies of A subunits alone. Indeed, there is evidence that the B subunit is not even expressed in the brain, although there is much evidence for its presence in the peripheral nervous system (Morales and Wang, 2002).

Mutations in Cys-loop receptors have been linked with a variety of neurological disorders. $5-\mathrm{HT}_{3}$ receptor antagonists were initially thought to have potential therapeutic use in disorders such as anxiety, depression, substance abuse, cognitive disorders, and schizophrenia, but clinical evidence has not to date been encouraging (Greenshaw and Silverstone, 1997). Nevertheless, a recent study identified two sequence variations in the 5$\mathrm{HT}_{\mathrm{A}}$ receptor subunit $\left(\mathrm{R}^{344} \mathrm{H}\right.$ and $\left.\mathrm{P}^{391} \mathrm{R}\right)$ in a small group of patients with bipolar disorder and schizophrenia (Niesler et al., 2001). The two mutations are located in the M3-M4 loop. This loop contains a number of potential phosphorylation sites and also has an important function in channel conductance and ion selectivity (Kelley et al., 2003; Unwin, 2000). Although each of the two mutations was only found in one patient out of the 428 schizophrenic individuals in the study population, given the large number of patients with this disorder (approx 1\% of the world's population) and the wide range of causal agents that influence the development and course of schizophrenia, these $5-\mathrm{HT}_{3}$ receptor mutations may play a role in this disease. In this study, we have examined the binding and functional properties of $\mathrm{R}^{344} \mathrm{H}$ and $\mathrm{P}^{391} \mathrm{R}$ mutants by expressing them in HEK293 cells to determine if there are any unusual characteristics of the mutant receptors that could contribute to the schizophrenic phenotype.

\section{Materials}

All cell culture reagents were obtained from Gibco BRL (Paisley, UK) except fetal calf serum, which was from Labtech International (Ringmer, UK). $\left[{ }^{3} \mathrm{H}\right]$ Granisetron $(81 \mathrm{Ci} /$ mmol) was from PerkinElmer (Boston MA). All other reagents were of the highest obtainable grade.

\section{Methods \\ Cell Culture}

Human embryonic kidney (HEK) 293 cells were grown on 90-mm tissue culture plates at $37^{\circ} \mathrm{C}$ and $7 \% \mathrm{CO}_{2}$ in a humidified atmosphere. They were cultured in Dulbecco's modified Eagle's medium (DMEM)/nutrient mix F12 (1:1) with GLUTAMAX I ${ }^{\mathrm{TM}}$ containing 10\% fetal calf serum, and passaged when confluent. Cells were transfected using calcium phosphate precipitation (Chen and Okayama, 1987) at 70-80\% confluency. Following transfection, cells were incubated for 3-4 $\mathrm{d}$ before being harvested for radioligand binding. Cells stably expressing wild-type, $\mathrm{R}^{344} \mathrm{H}$ and $\mathrm{P}^{391} \mathrm{R}$ receptors were constructed as previously described (Hargreaves et al., 1994) and plated onto $18-\mathrm{mm}^{2}$ glass coverslips for electrophysiological experiments. 


\section{Site-Directed Mutagenesis}

Mutagenesis reactions were performed using the method described by Kunkel (1985) using the 5- $\mathrm{HT}_{3 \mathrm{~A}(\mathrm{~b})}$ subunit DNA (Accession: AY605711) as described previously (Hargreaves et al., 1996). Oligonucleotide primers were designed according to the recommendations of Sambrook et al. (1989), and some suggestions of the Primer Generator (Turchin and Lawler 1999) (http://www.med.jhu.edu/medcenter/primer/primer.cgi). A silent restriction site was incorporated into each primer to assist rapid identification of mutants.

\section{Radioligand Binding}

This was undertaken as previously described (Lummis et al., 1993) with minor modifications. Briefly, HEK293 cells that had been transfected with wild-type or mutant DNA were washed twice with phosphate-buffered saline (PBS) at room temperature. They were then scraped into $1 \mathrm{~mL}$ of ice-cold HEPES buffer $(10 \mathrm{~m} M, \mathrm{pH} 7.4)$ containing the following proteinase inhibitors (PIs): $1 \mathrm{~m} M$ EDTA, $50 \mu \mathrm{g} / \mathrm{mLsoybean}$ trypsin inhibitor, 5 $\mu \mathrm{g} / \mathrm{mL}$ bacitracin, and $0.1 \mu M$ phenylmethylsulfonyl fluoride (PMSF). Harvested cells were washed in HEPES/PI and frozen at $-20^{\circ} \mathrm{C}$. After thawing, they were washed twice with HEPES buffer, resuspended, and $50 \mu \mathrm{g}$ of cell membranes were incubated in $0.5 \mathrm{~mL}$ HEPES buffer containing $0.02-2 \mathrm{nM}\left[{ }^{3} \mathrm{H}\right]$ granisetron. Nonspecific binding was determined using $1 \mu M \mathrm{~d}$-tubocurarine. Reactions were incubated for $1 \mathrm{~h}$ at $4^{\circ} \mathrm{C}$ and were terminated by rapid vacuum filtration using a Brandel cell harvester onto GF/B filters presoaked for $3 \mathrm{~h}$ in $0.3 \%$ polyethyleneimine followed by two rapid washes with $4 \mathrm{~mL}$ ice-cold HEPES buffer. Radioactivity was determined by scintillation counting (Beckman LS60000SC). Protein concentration was estimated using the Bio-Rad Protein Assay with BSAstandards. Data were analyzed by iterative curve fitting (GraphPad, PRISM, San Diego, CA) according to the equation: $\left.B=\left(B_{\max } \cdot[\mathrm{L}]\right) / \mathrm{K}_{\mathrm{d}}+[\mathrm{L}]\right)$, where $B$ is bound radioligand, $B_{\max }$ is maximum binding at equilibrium, $\mathrm{K}_{\mathrm{d}}$ is the equilibrium dissociation constant, and [L] is the free concentration of radioligand.

\section{Electrophysiology}

Electrophysiological measurements were performed in the whole-cell configuration using an Axopatch 200 amplifier (Axon Instruments, Union City, CA), Lab-PC+ A/D board (National Instruments, Inc.), and the Strathclyde Electrophysiology Software Package (Department of Physiology and Pharmacology, University of Strathclyde, UK; http:// www.strath.ac.uk/Departments/PhysPharm/). All experiments were performed in voltageclamp mode. Currents were filtered at a frequency of $5 \mathrm{kHz}(-3 \mathrm{~dB})$, using the 4-pole lowBass Bessel filter provided on the amplifier, and acquired at a sampling frequency of $1 \mathrm{kHz}$. The cell membrane potential was routinely held at $-60 \mathrm{mV}$. Patch electrodes were pulled with a Sutter P87 (Novato, CA) using a three-stage vertical pull and type GC120TF-10 borosilicate glass (Harvard Apparatus, Edenbridge, Kent, UK). Pipet resistances ranged from 2.0 to $3.5 \mathrm{M} \Omega$ and voltage errors never exceeded $5 \mathrm{mV}$.

Rapid application of solutions was achieved using a ValveBank 8II (Automate Scientific Inc., San Francisco, CA). Cells were perfused using a gravity-fed bath with a constant laminar flow of saline at a rate of $4-5 \mathrm{~mL}$ per min. Using the time taken for the liquid junction potential to restabilize after changing saline concentration as an indicator of solution exchange, it was established that cells were completely submersed in test solution within less than $150 \mathrm{~ms}$. The time taken for the baseline current to achieve a new stable baseline value was used as an estimate of the time for solution exchange. After entering the whole-cell configuration, the membrane current was allowed to stabilize for at least $2 \mathrm{~min}$ before recordings were made. 
For dose-response experiments, patch pipets were filled with filtered $(0.2 \mu \mathrm{m}$, Millipore) intracellular saline containing (in $\mathrm{mM}$ ) $140 \mathrm{CsCl}, 1.0 \mathrm{MgCl}_{2}, 1.0 \mathrm{CaCl}_{2}, 10.0$ EGTA, and 10 HEPES; pH 7.2 with CsOH. Cells were continuously perfused with an extracellular solution containing $140 \mathrm{NaCl}, 5.4 \mathrm{KCl}, 1.0 \mathrm{MgCl}_{2}$, and 10 HEPES; pH 7.2 with $\mathrm{NaOH}$. Test solutions were dissolved in extracellular saline. Both test solutions and salines were prepared fresh each day.

Currents were analyzed using the software tools provided as part of the Strathclyde Electrophysiology Software. Current activation and desensitization were fitted (5-95\% of total current) to a standard single-exponential function. Statistical analysis and curve fitting was performed using Prism V3.02 (GraphPad Software, San Diego, CA; www.graphpad.com). Data are reported as means \pm S.E.M. Statistical analyses were performed using Student's t-test, with $p$ values $<0.05$ considered statistically significant.

\section{Immunofluorescence Localization}

This was as described previously (Spier et al., 1999). Briefly, transfected cells were washed with three changes of Tris-buffered saline (TBS: $0.1 M$ Tris, $\mathrm{pH} 7.4,0.9 \% \mathrm{NaCl}$ ) and fixed using ice-cold 4\% paraformaldehyde in phosphate buffer (PB: $66 \mathrm{mMNa} \mathrm{NPO}_{4}, 39 \mathrm{mM}$ $\mathrm{NaH}_{2} \mathrm{PO}_{4}, \mathrm{pH}$ 7.2). After two TBS washes, the cells were incubated overnight at $4{ }^{\circ} \mathrm{C}$ in pAb120; at 1:1600 in TBS. Biotinylated anti-rabbit IgG (Vector Laboratories, CA) and fluorescein isothiocyanate (FITC) avidin D (Vector Laboratories, CA) were used to detect bound antibody as per the manufacturer's instructions. Coverslips were mounted in Vectashield mounting medium (Vector Laboratories, CA) and immunofluorescence observed using a confocal microscope.

\section{Results}

\section{Radioligand Binding}

Radioligand binding demonstrated that the affinity of the $5-\mathrm{HT}_{3}$ antagonist, $\left[{ }^{3} \mathrm{H}\right]$ granisetron, was not significantly different than wild-type for either $\mathrm{R}^{344} \mathrm{H}$ or $\mathrm{P}^{391} \mathrm{R}$ mutant receptors (Table 1). $\mathrm{B}_{\max }$ (maximum number of binding sites) values were also not significantly different.

\section{Electrophysiological Analysis}

Application of 5-HT to HEK 293 cells expressing wild-type or mutant receptors produced rapidly activating inward currents that desensitized over the time-course of the application. Representative examples of whole-cell currents recorded from wild-type and mutant receptors are shown in Fig. 2A-C. Application of varying concentrations of 5-HT showed the response was dose-dependent (Fig. 2D). Wild-type receptors displayed an $\mathrm{EC}_{50}$ of 1.68 $\mu M \pm 0.01(n=38) . \mathrm{EC}_{50}$ values for $\mathrm{R}^{344} \mathrm{H}(1.70 \mu M \pm 0.02, n=18)$ were not significantly different than wild-type, but $\mathrm{EC}_{50}$ values for $\mathrm{P}^{391} \mathrm{R}$ receptors showed a small but significant increase $\left(\mathrm{EC}_{50}=2.73 \mu M \pm 0.01 ; p<0.001, n=8\right)$. Hill co-efficients for $\mathrm{R}^{344} \mathrm{H}(2.15 \pm$ $0.18)$ and $\mathrm{P}^{391} \mathrm{R}(2.44 \pm 0.09)$ were indistinguishable from wild-type (1.85 \pm 0.17$)$.

Activation and desensitization data are shown in Fig. 3. For both wild-type and mutant receptors, the time constants for activation and desensitization decreased as the concentration of 5-HT was raised. Mutant receptors displayed time constants that were not significantly different than wild-type receptors at all 5-HT concentrations.

\section{Immunofluorescent Localization}

Untransfected cells displayed very low levels of immunofluorescence, confirming that crossreactivity with native cell proteins was almost absent (Fig. 4). Immunofluorescence of 
nonpermeabilized cells expressing wild-type and mutant receptors confirmed that the receptors were expressed on the cell surface.

\section{Discussion}

The presence of two mutations $\left(\mathrm{R}^{344} \mathrm{H}\right.$ and $\left.\mathrm{P}^{391} \mathrm{R}\right)$ in the $5-\mathrm{HT}_{3}$ receptor sequence variants in patients suffering from schizophrenia introduces the possibility that mutations in this receptor contribute to their neurological disease, and could be significant in its heritable nature. In this study, we show that one of the two mutations $\left(\mathrm{P}^{391} \mathrm{R}\right)$ causes a small but significant increase in $\mathrm{EC}_{50}$, while the second mutation $\left(\mathrm{R}^{344} \mathrm{H}\right)$ appears to have no significant effects on the function of the receptor. Although the scope of our experiments was limited to measurements of whole-cell currents, these data suggest that the $\mathrm{R}^{344} \mathrm{H}$ mutation does not play a role in schizophrenia, but the $\mathrm{P}^{391} \mathrm{R}$ mutation may contribute to the pathology of the disease. The mutations are discussed individually in more detail below.

A substitution of arginine for histidine $\left(\mathrm{R}^{344} \mathrm{H}\right)$ is a conservative change, as the properties of the two amino acids are broadly similar. Consequently, it is not surprising that both the binding and functional characteristics of the $\mathrm{R}^{344} \mathrm{H}$ mutant were similar to wild-type receptors. However, it is possible that this mutation does modify receptor function in a way that was not identified in this study. The mutation is located in the intracellular M3-M4 loop of the receptor, which is known to be involved in receptor synthesis, transport, clustering, and anchoring (reviewed in Karlin, 2002). The studies we performed have shown that the $\mathrm{R}^{344} \mathrm{H}$ mutant receptor is translated, expressed, and reaches the cell surface. However, this mutation could potentially disrupt receptor clustering and/or localization in its native environment, as has been suggested for the link between epilepsy and $\mathrm{GABA}_{\mathrm{A}}$ dysfunction (Macdonald et al., 2004). For example, recent work suggests that intracellular domains of 5$\mathrm{HT}_{3}$ receptors can associate with the microtubule-associated protein $1 \mathrm{~B}$ and may be clustered by this protein in neurons in a similar way to rapsyn clustering of nACh receptors (Sun et al., 2004). A structural change introduced by a mutation such as $\mathrm{R}^{344} \mathrm{H}$ might interfere with this clustering process. There is also the possibility that this mutation might interfere with receptor phosphorylation. The M3-M4 loop contains several putative phosphorylation sites. Although to date, only one site has been shown to be phosphorylated (Lankiewicz et al., 2000), there is evidence that phosphorylation can alter both the macroscopic current (Coultrap and Machu, 2002; Hubbard et al., 2000; Sun et al., 2003; Zhang and Weight, 1995) and single-channel conductance (Van Hooft and Vijverberg, 1995). Therefore, in a different environment, for example where there are high levels of the appropriate kinases and/or phosphatases, the presence of an $\mathrm{R}^{344} \mathrm{H}$ mutation might affect receptor activity. Substituting a proline for an arginine residue, as in the $\mathrm{P}^{391} \mathrm{R}$ mutation, has the potential to cause a large change in the protein. Proline is a small, rigid, neutral amino acid that lacks the ability to act as an $\mathrm{H}$-bond donor, while arginine is a large, flexible, positively charged amino acid that can form both $\mathrm{H}$-bonds and salt bridges in and between proteins. Indeed, in the extracellular domain of the 5- $\mathrm{HT}_{3}$ receptor, changing any one of the conserved for prolines to alanine eliminates functional expression of the protein (Deane and Lummis, 2001). Therefore, it is not surprising that the $\mathrm{P}^{391} \mathrm{R}$ mutation has an effect on 5$\mathrm{HT}_{3}$ receptor function. This change is not due to a global effect on the protein structure, as immunofluorescence data showed that the receptor was correctly inserted into the membrane and radioligand binding data showed a similar $\left[{ }^{3} \mathrm{H}\right]$ granisetron binding affinity to wild-type receptors, indicating the structure of the ligand-binding domain was unaffected. This lack of change in binding affinity also suggests that a change in $\mathrm{EC}_{50}$, a parameter that encompasses both binding and gating effects, is primarily due to a change in receptor gating.

Consequently, our data suggest that changing the $\mathrm{P}^{391} \mathrm{R}$ mutation has a deleterious effect on gating. Unfortunately, there is currently no structural information about this region of the 
protein, so we cannot predict the effect of such a change, but proline is conserved here in all $5-\mathrm{HT}_{3 \mathrm{~A}}$ receptor subunits, suggesting some role in structure and/or function.

A similar study (published during the course of this work) did not record a change in $\mathrm{EC}_{50}$ in $\mathrm{P}^{391} \mathrm{R}$ mutant receptors (Kurzwelly et al., 2004). This appears to conflict with our data, but may be due to their use of outside-out patches, which yield smaller currents and more variability than the whole-cell recording that we performed. As the change we observed was small, it may have been obscured in the studies performed by Kurzwelly et al. (2004).

Changes in $\mathrm{EC}_{50}$ caused by point mutations are thought to contribute to disease characteristics in a range of ligand-gated ion channels, including glycine, $\mathrm{GABA}_{\mathrm{A}}$, and $\mathrm{nACh}$ receptors. Some of these changes are very large. For example, the R271Q mutation in the glycine receptor, which is responsible for the inheritable disorder hyperekplexia, results in a 667-fold change in $\mathrm{EC}_{50}$ (Lynch et al., 1997). However, other changes in $\mathrm{EC}_{50}$ are smaller. In the glycine receptor, a proline to threonine mutation within the intracellular M1M2 loop has been shown to cause a 2.25-fold shift in the $\mathrm{EC}_{50}$ and has been positively correlated with hyperplexia (Saul et al., 1999). Consequently, our observed change in the $\mathrm{P}^{391} \mathrm{R}$ mutant $\mathrm{EC}_{50}$ could also have an important physiological consequence. For example, it is believed that the primary role of $5-\mathrm{HT}_{3}$ receptors in the CNS may be the modulation of other neurotransmitter-derived responses, such as the 5-HT-induced increase in GABAergic inhibitory post-synaptic potentials (IPSPs) in hippocampal slices (McMahon et al., 1997; Morales et al., 1996; Ropert and Guy, 1991). We hypothesize that altering modulation of this or any other IPSPs would have significant neuronal effects that might contribute to the pathology of schizophrenia. It is also of importance that the steep Hill coefficient of 5- $\mathrm{HT}_{3}$ receptor responses means that a small change in the 5-HT concentration would have a large effect on the macroscopic current, which could be magnified through its modulatory effect on a secondary response.

In conclusion, examination of the properties of two $5-\mathrm{HT}_{3}$ receptor mutations found in schizophrenic patients showed that $\mathrm{R}^{344} \mathrm{H}$ had no significant effect on the function of the mutant receptor. In contrast, the presence of the $\mathrm{P}^{391} \mathrm{R}$ mutation increased the $\mathrm{EC}_{50}$, but did not alter other properties of the response. Combined with the rare occurrence of these mutations, our results imply that neither of these mutations are likely to present a major contribution to the pathology of schizophrenia. However, the results do suggest that, for a small group of individuals, the $\mathrm{P}^{391} \mathrm{R}$ mutation may have a role in the etiology of this disorder.

\section{References}

Alex KD, Yavanian GJ, McFarlane HG, Pluto CP, Pehek EA. Modulation of dopamine release by striatal 5-HT2C receptors. Synapse. 2005; 55:242-251. [PubMed: 15668911]

Chen C, Okayama H. High-efficiency transformation of mammalian cells by plasmid DNA. Mol. Cell Biol. 1987; 7:2745-2752. [PubMed: 3670292]

Coultrap SJ, Machu TK. Enhancement of 5-hydroxytryptamine3A receptor function by phorbol 12myristate, 13-acetate is mediated by protein kinase $\mathrm{c}$ and tyrosine kinase activity. Receptors Channels. 2002; 8:63-70. [PubMed: 12448787]

Deane CM, Lummis SC. The role and predicted propensity of concerved proline residues in the $5-\mathrm{HT}_{3}$ receptor. J. Biol. Chem. 2001; 276(37):962-37. 966.

Gaddum JH, Hameed KA. Drugs which antagonize 5-hydroxytryptamine. Br. J. Pharmacol. 1954; 9:240-248.

Greenshaw AJ, Silverstone PH. The nonantiemetic uses of serotonin 5-HT 3 receptor antagonists. Clinical pharmacology and therapeutic applications. Drugs. 1997; 53:20-39. [PubMed: 9010647] 
Hargreaves AC, Gunthorpe MJ, Taylor CW, Lummis SC. Direct inhibition of 5-hydroxytryptamine3 receptors by antagonists of L-type $\mathrm{Ca}^{2+}$ channels. Mol. Pharmacol. 1996; 50:1284-1294. [PubMed: 8913360]

Hargreaves AC, Lummis SC, Taylor CW. $\mathrm{Ca}^{2+}$ permeability of cloned and native 5hydroxytryptamine type 3 receptors. Mol. Pharmacol. 1994; 46:1120-1128. [PubMed: 7808432]

Hubbard PC, Thompson AJ, Lummis SC. Functional differences between splice variants of the murine 5-HT3(A) receptor: possible role for phosphorylation. Brain Res. Mol. Brain Res. 2000; 81:101108. [PubMed: 11000482]

Karlin A. Emerging structure of the nicotinic acetylcholine receptors. Nat. Rev. Neurosci. 2002; 3:102-114. [PubMed: 11836518]

Kelley SP, Dunlop JI, Kirknes EF, Lambert JJ, Peters JA. A cytoplasmic region determines singlechannel conductance in 5-HT 3 receptors. Nature. 2003; 424:321-324. [PubMed: 12867984]

Kunkel TA. Rapid and efficient site-specific mutagenesis without phenotypic selection. Proc. Natl. Acad. Sci. U. S. A. 1985; 82:488-492. [PubMed: 3881765]

Kurzwelly D, Barann M, Kostanian A, Combrink S, Bonishc H, Gothert M, Bruss M. Pharmacological and electrophysiological properties of the naturally occurring Pro391Arg variant of the human 5$\mathrm{HT}_{3 \mathrm{a}}$ receptor. Pharmacogenetics. 2004; 14:165-172. [PubMed: 15167704]

Lankiewicz S, Huser MB, Heumann R, Hatt H, Gisselmann G. Phosphorylation of the 5hydroxytryptamine3 (5-HT 3 ) receptor expressed in HEK 293 cells. Receptors Channels. 2000; 7:9-15. [PubMed: 10800772]

Levkovitz Y, Arnest G, Mendlovic S, Treves I, Fennig S. The effect of Ondansetron on memory in schizophrenic patients. Brain Res. bull. 2005; 65:291-295. [PubMed: 15811593]

Lummis SC, Sepulveda MI, Kilpatrick GJ, Baker J. Characterization of [ $\left.{ }^{3} \mathrm{H}\right]$ metachlorophenylbiguanide binding to $5-\mathrm{HT}_{3}$ receptors in N1E-115 neuroblastoma cells. Eur. J. Pharmacol. 1993; 243:7-11. [PubMed: 8253126]

Lynch JW, Rajendra S, Pierce KD, Handford CA, Barry PH, Schofield PR. Identification of intracellular and extracellular domains mediating signal transductin in the inhibitory glycine receptor chloride channel. EMBO. J. 1997; 16:110-120. [PubMed: 9009272]

Macdonald RL, Gallagher MJ, Feng HJ, Kang J. GABA(A) receptor epilepsy mutations. Biochem. Pharmacol. 2004; 68:1497-1506. [PubMed: 15451392]

Maricq AV, Peterson AS, Brake AJ, Myers RM, Julius D. Primary structure and functional expression of the $5 \mathrm{HT}_{3}$ receptor, a serotonin-gated ion channel. Science. 1991; 254:432-437. [PubMed: 1718042]

McMahon LL, Kauer JA. Hippocampal interneurons are excited via serotonin-gated ion channels. J. Neurophysiol. 1997; 78:2493-2502. [PubMed: 9356400]

Meltzer HY. Clinical studies on the mechanism of action of clozapine: the dopamine-serotonin hypothesis of schizophrenia. Psychopharmacology (Berl). 1989; 99(Suppl):S18-S27. [PubMed: 2682729]

Meltzer, HY.; Fatemi, SH. The role of serotonin in schizophrenia nad the mechanism of action of antipsychotic drugs. Serotonergic mechanisms. In: Kane, JM.; Moller, H-J.; Awouters, F., editors. Antipsychotic Treatment. New York: Marcel Dekker; 1996. p. 77-107.

Meltzer HY, Li Z, Kaneda Y, Ichikawa J. Serotonin receptors: their key role in drugs to treat schizophrenia. Prog. Neuropsychopharmacol. Biol. Psychiatry. 2003; 27:1159-1172. [PubMed: 14642974]

Morales M, Battenberg E, de Lecea L, bloom FE. The type 3 serotonin receptor is expressed in a subpopulation of GABAergic neurons in the rat neo-cortex and hippocampus. Brain Res. 1996; 731:199-202. [PubMed: 8883870]

Morales M, Wang SD. Differential composition of 5-hydroxytryptamine3 receptors synthesized in the rat CNS and peripheral nervous system. J. Neurosci. 2002; 22:6732-6741. [PubMed: 12151552]

Niesler B, Weiss B, Fischer C, Nothen MM, Propping P, Bondy B, Rietschel M, Maier W, Albus M, Franzek E, Rappold GA. Serotonin receptor gene HTR3A variants in schizophrenic and bipolar affective patients. Pharmacogenetics. 2001; 11:21-27. [PubMed: 11207027]

Ropert N, Guy N. Serotonin facilitates GABAergic transmission in the CA1 region of rat hippocampus in vitro. J. Physiol. 1991; 441:121-136. [PubMed: 1687746] 
Sambrook, J.; Fritsch, EF.; Maniatis, T. Molecular Clonin: A Laboratory Manual. Cold Spring Harbor, NY: Cold Spring Harbor Laboratory; 1989.

Saul B, Kuner T, Sobetzko D, Brune W, Hanefeld F, Meinck HM, Becker CM. Novel GLRA1 missense mutation (p250T) in dominant hyperekplexia defines an intracellular determinant of blycine receptor channel gatin. J. Neurosci. 1999; 19:869-877. [PubMed: 9920650]

Spier AD, Wotherspoon G, Nayak SV, Nichols RA, Priestley JV, Lummis SCR. Antibodies against the extacellular domain of the 5- $\mathrm{HT}_{3}$ receptor label both native and recombinant receptors. Mol. Brain Res. 1999; 67:221-230. [PubMed: 10216220]

Sun, H.; Hu, X.; Schoenebeck, J.; Peoples, R.; Kimmel, C.; Zhang, L. Washinton, DC: Society for Neuroscience; 2004. Identification of a direct interaction between the 5- $\mathrm{HT}_{3 \mathrm{~A}}$ receptor and the light chain of microtubule-associated protein 1b. Program No. 626.9 2004 Abstract Viewer/ Itinerary Planner2004. Online

Sun H, Hu XQ, Moradel EM, Weight FF, Zhang L. Modulation of 5- $\mathrm{HT}_{3}$ receptor-mediated response and trafficking by activation of protein kinase C. J. Biol. Chem. 2003; 278(34):150-34. 157.

Thompson AJ, Lummis SC. A single ring of charged amino acids at one end of the pore can control ion selectivity in the 5-HT 3 receptor. Br. J. Pharmacol. 2003; 140:359-365. [PubMed: 12970096]

Turchin A, Lawler JF Jr. The primer generator: a program that facilitates the selection of oligonucleotides for site-directed mutagenesis. Biotechniques. 1999; 26:67-676.

Unwin N. The Croonian Lecture 2000. Nicotinic acetylcholine eceptor and the structural basis of fast synaptic transmission. Philos. Trans. R. Soc. Lond. B. Biol. Sci. 2000; 355:1813-1829. [PubMed: 11205343]

Van Hooft JA, Vijverberg HP. Phosphorylation controls conductance of 5-HT 3 receptor ligand-gated ion channels. Receptors Channels. 1995; 3:7-12. [PubMed: 8589995]

Wooley DW, Shaw E. A biochemical and Pharmacological suggestion about certain mental disorders. Porc. Natl. acad. Sci. U. S. A. 1954; 40:228-231.

Zhang L, Oz M, Weight FF. Potentiation of $5-\mathrm{HT}_{3}$ receptor-mediated responses by protein kinase C activation. Neuroreprot. 1995; 6:1464-1468. 

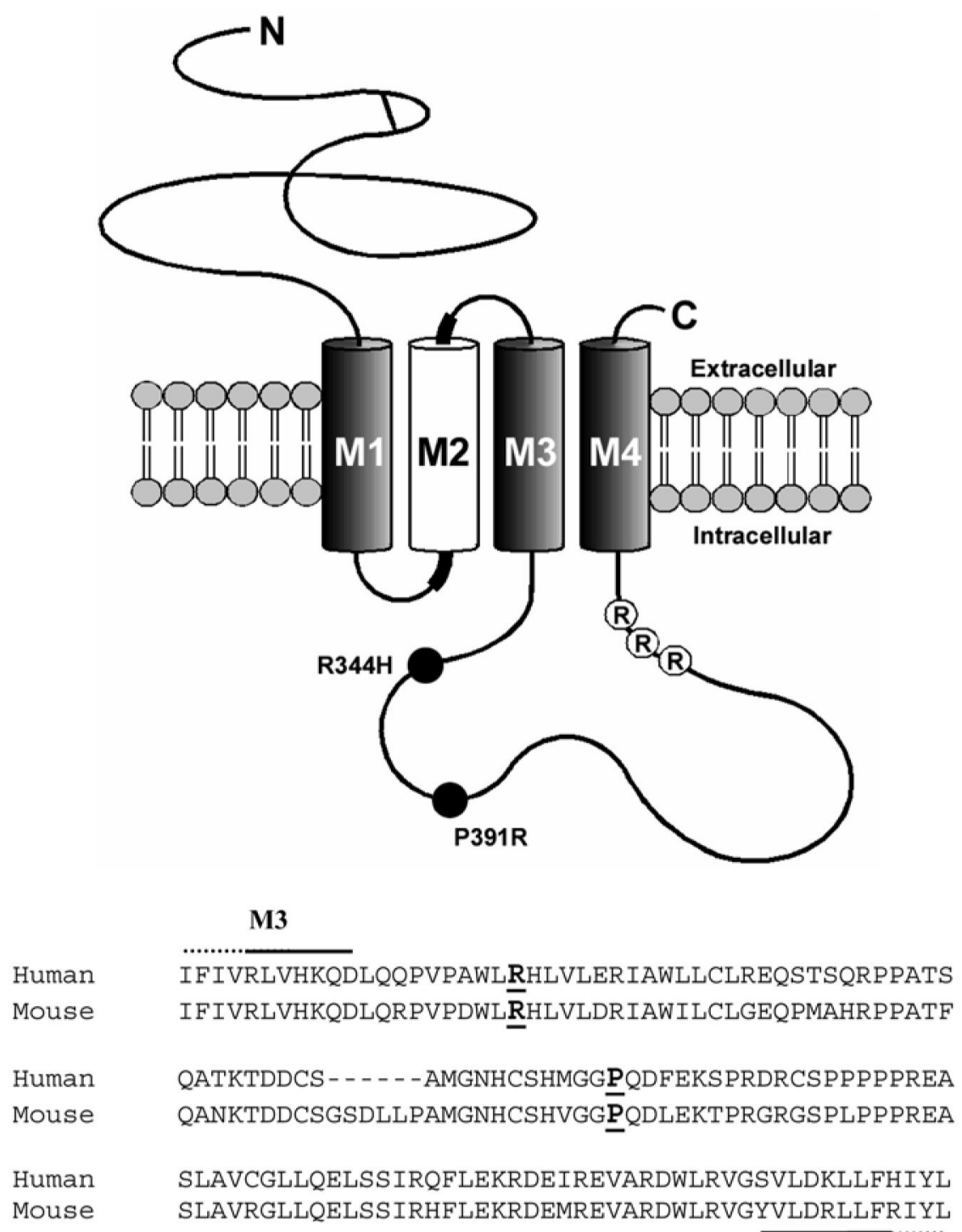

M4

Fig. 1.

Schematic representation of the 5-HT 3 receptor showing the location of the $\mathrm{R}^{344} \mathrm{H}$ and $\mathrm{P}^{391} \mathrm{R}$ mutations. The M3-M4 region that has been linked to ion conductivity is highlighted (R-R-R) in the M3-M4 loop (Kelley et al., 2003). Regions associated with ion selectivity (Thompson and Lummis, 2003) are highlighted by thick black lines at either end of the central pore-lining M2 region (white cylinder). None of these important functional areas lies close to the mutations in this study. The amino-acid sequence-alignment of the human and mouse intracellular M3-M4 loop is shown below. $\mathrm{R}^{344}$ and $\mathrm{P}^{391}$ are in bold and underlined. 


\section{A Wild type}

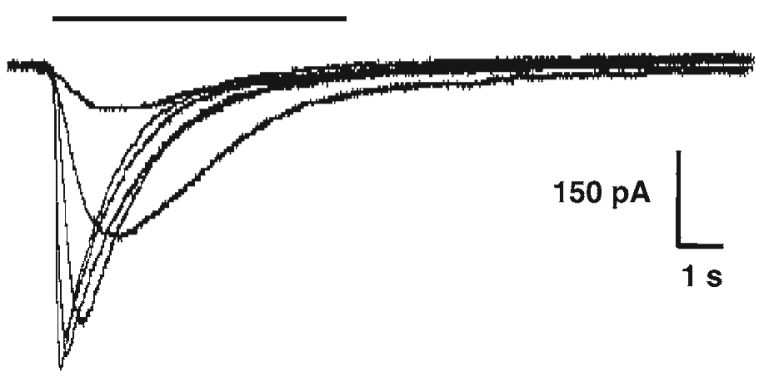

\section{B R344H}

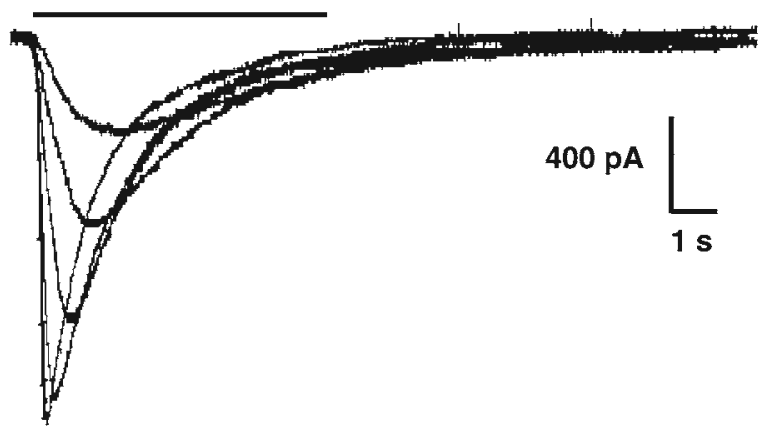

\section{P391R}

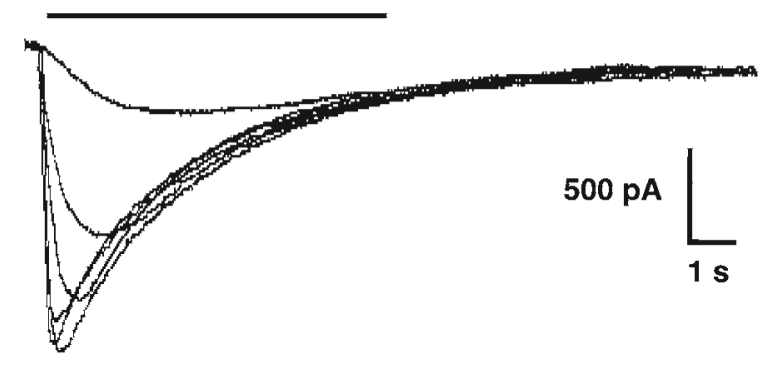

D

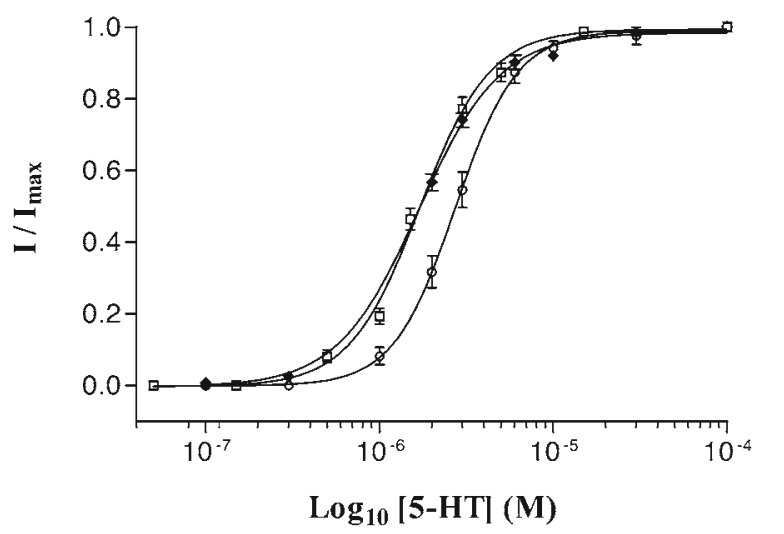

Fig. 2.

Representative current traces for wild-type and mutant receptors. A range of responses at different 5-HT concentrations is shown for wild-type $(0.6-10 \mu M), \mathrm{R}^{344} \mathrm{H}(0.6-10 \mu M)$, and $\mathrm{P}^{391} \mathrm{R}(1-30 \mu M)$. Dose-response curves for wild-type and mutant 5-HT 3 receptors taken from thse and other data are shown in the lower right panel. All currents were normalized to the maximum response. Wild-type, filled diamond, $n=38 ; \mathrm{R}^{344} \mathrm{H}$, open square, $n=18$; $\mathrm{P}^{391} \mathrm{R}$, open circle, $n=8$. 

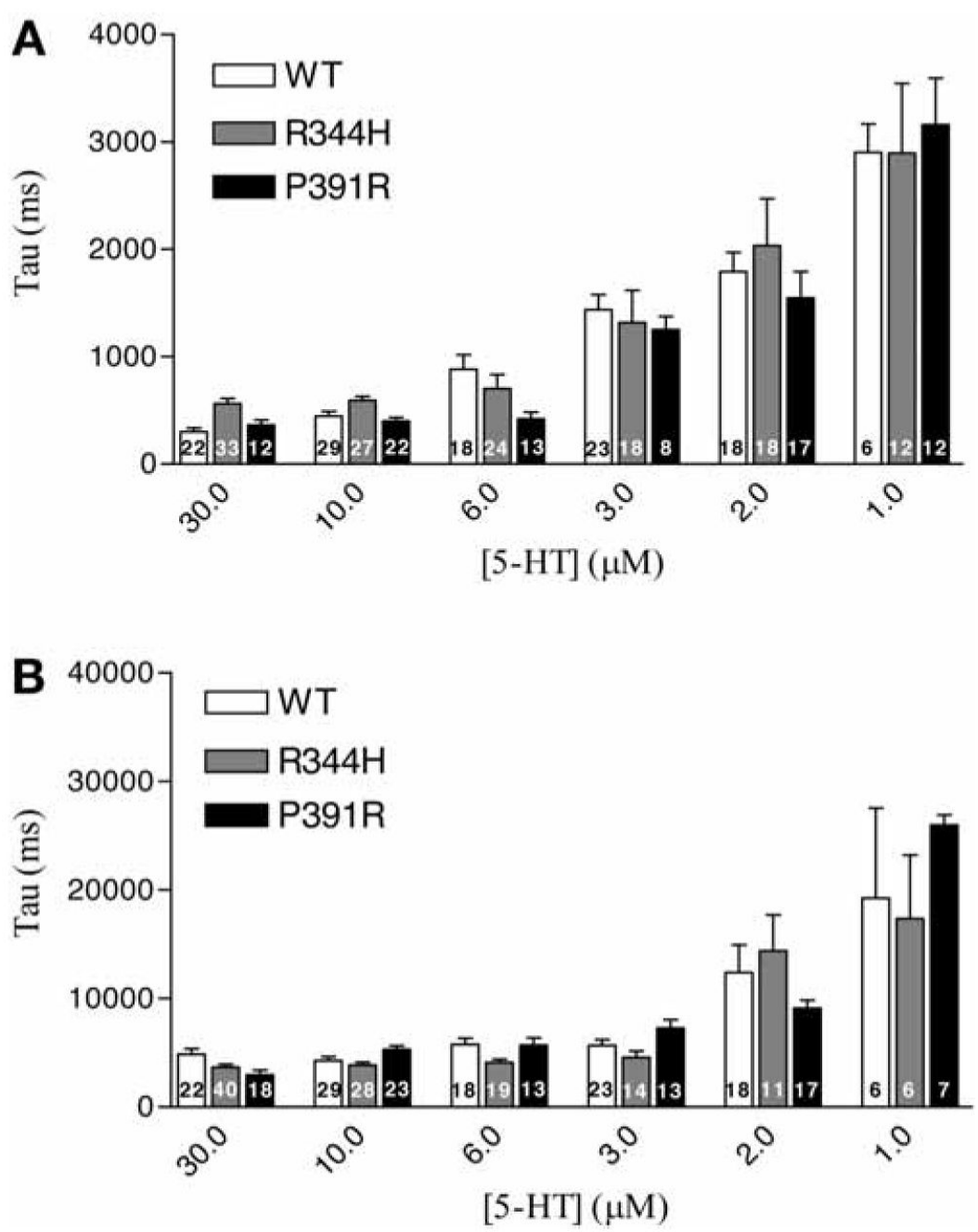

Fig. 3.

Time constants $(\boldsymbol{\tau})$ for activation $(\mathbf{A})$ and desensitization $(\mathbf{B})$ of wild-type and mutant receptors recorded over a range of 5-HT concentrations. Sample size is shown at the bottom of each bar. 

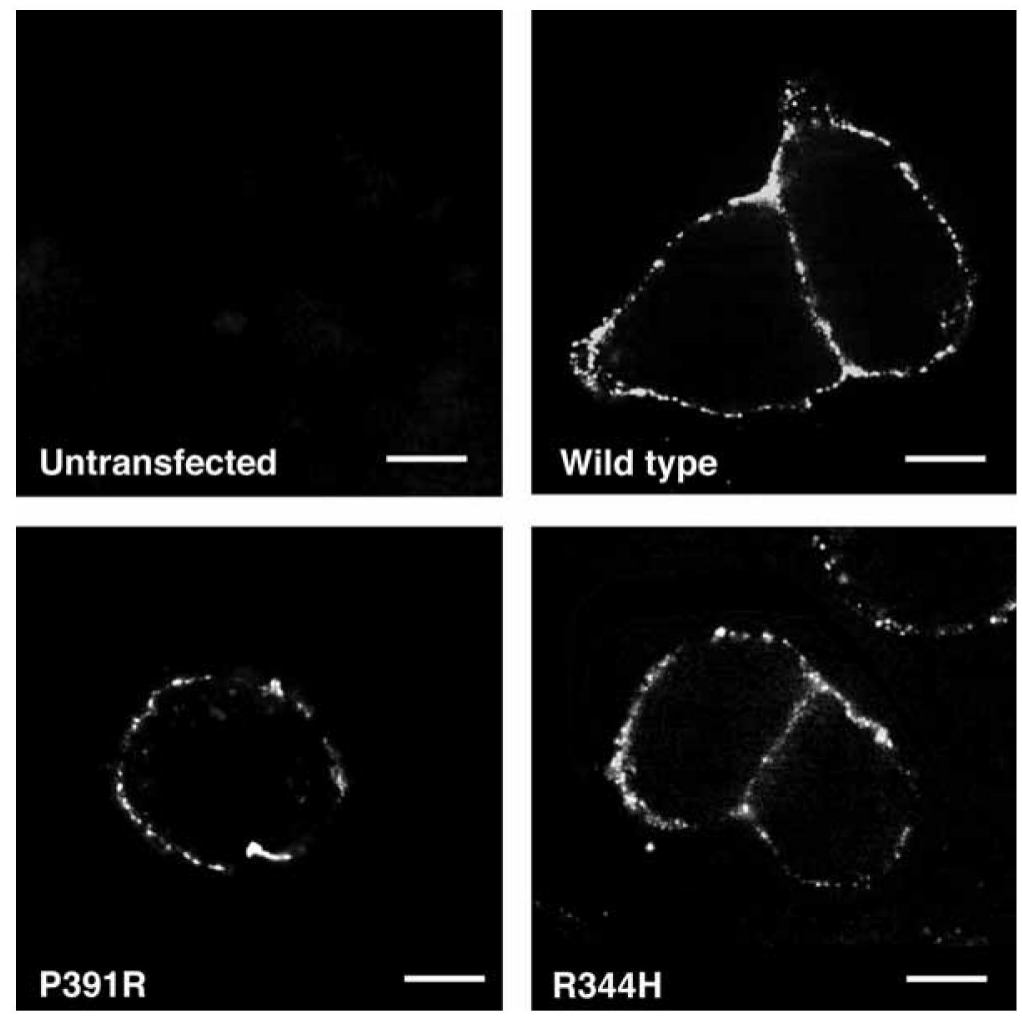

Fig. 4.

Immunofluorescent labeling of wild-type and mutant receptors on the surface of human embryonic kidney (HEK) 293 cells. Antibody was directed against the extracellular Nterminal region of the $5-\mathrm{HT}_{3}$ receptor (Spier et al., 1999). Scale bar $=10 \mu M$. 
Table 1

Binding Affinities of mutant 5- $\mathrm{HT}_{3}$ Receptors for $\left[{ }^{3} \mathrm{H}\right]$ Granisetron

\begin{tabular}{lccc}
\hline Genotype & $\mathbf{K}_{\mathbf{d}}(\mathbf{n M})$ & $\mathbf{B}_{\mathbf{m a x}}(\mathbf{f m o l} / \mathbf{m g})$ & Sample size $(\boldsymbol{n})$ \\
\hline Wild-type & $0.63 \pm 0.11$ & $567 \pm 149$ & 5 \\
R344H & $0.56 \pm 0.04$ & $853 \pm 232$ & 9 \\
P391R & $0.52 \pm 0.05$ & $353 \pm 113$ & 5 \\
\hline
\end{tabular}

